\title{
ANALISIS POSTUR KERJA SECARA ERGONOMI PADA OPERATOR PENCETAKAN PILAR YANG MENIMBULKAN RISIKO MUSCULOSKELETAL
}

\author{
Annisa Purbasari ${ }^{1}$, Maria Azista ${ }^{2}$, Benedikta Anna H. Siboro ${ }^{3}$ \\ ${ }^{1,2}$ Teknik Industri, Fakultas Teknik, Universitas Riau Kepulauan \\ ${ }^{3}$ Manajemen Rekayasa, Institut Teknologi Del \\ E-mail : annisapurbasari@gmail.com ${ }^{1}$
}

\begin{abstract}
ABSTRAK
CV. XYZ merupakan suatu industri kecil yang bergerak pada proses produksi pilar. Sebagian besar aktivitas kerja bersifat manual. Penelitian ini bertujuan untuk menganalisis postur kerja operator pencetakan pilar yang menimbulkan risiko musculoskeletal. Subyek penelitian adalah enam orang operator laki-laki yang ditempatkan pada area pencetakan. Penilaian dilakukan dengan menggunakan metode QEC (Quick Exposure Check), selanjutnya jika nilai yang didapat menganjurkan perbaikan, maka dilakukan survei dengan menggunakan kuesioner NBM (Nordic Body Map). Berdasarkan hasil dari penilaian QEC diperlukan penelitian lebih lanjut dan dilakukan perubahan terhadap postur kerja operator tersebut, kemudian dilanjutkan pada survei kuesioner NBM. Hasil dari kuesioner ini didapatkan beberapa titik tingkat keparahan rasa sakit atas risiko gangguan musculoskeletal dibeberapa bagian tubuh yaitu leher (50\%), bahu kiri (50\%), bahu kanan (50\%), pinggul (66,67\%), paha kiri $(83,33 \%)$, paha kanan $(83,33 \%)$, lutut kiri $(83,33 \%)$, lutut kanan $(83,33 \%)$, dan lengan atas $(66,67 \%)$. Sedangkan tingkat keparahan rasa sangat sakit atas risiko gangguan musculoskeletal adalah punggung $(66,67 \%)$.
\end{abstract}

Kata kunci: Postur Kerja, Quick Exposure Check, Nordic Body Map, Musculoskeletal

\begin{abstract}
CV. XYZ is a small industry that is engaged in the production process of pillars. Most work activities are manual. This study aims to analyze the working posture of the pillar printing operator that pose musculoskeletal risk. The research subject were six male operators who were placed on the printing area. The assessment is done by using QEC (Quick Exposure Check) method, then if the obtained value recommends improvement, then a survey is conducted using the NBM (Nordic Body Map) questionnaire. Based on the results of the QEC assessment further research required and changes to the operator's work posture, then proceed to the NBM questionnaire. The results of this questionnaire were obtained several points in the severity of the pain for musculoskeletal disorders risk in some parts of the body such as the neck (50\%), left shoulder (50\%), right shoulder (50\%), hips (66.67\%), left thigh (83.33\%), right thigh (83.33\%), left knee (83.33\%), right knee (83.33\%), and the upper arm (66.67\%). While the severity of pain is very painful for musculoskeletal disorders risk is the back (66.67\%).
\end{abstract}

Keywords:. Work Posture, Quick Exposure Check, Nordic Body Map, Musculoskeletal 


\section{PENDAHULUAN}

Sektor Industri kecil dan menegah (IKM) merupakan salah satu penyangga ekonomi dan tulang punggung perekonomian nasional khususnya di Indonesia. Hal ini disebabkan IKM berperan penting untuk pertumbuhan perekonomian bangsa berupa penyerapan tenaga kerja. Pada umumnya aktivitas produksi di sektor IKM masih banyak ditemukan pekerjaan secara manual yang dilakukan oleh tenaga manusia, sehingga dikhawatirkan akan mempengaruhi postur kerja serta kesehatan dan keselamatan kerja (K3) operator sebagai tenaga kerjanya. Jika pekerjaan secara manual yang mengabaikan kesehatan dan keselamatan kerja, maka akan menimbulkan kelelahan dan cidera yang mengurangi performansi kinerja operator. Berbagai aktivitas pada pekerjaan secara manual dilakukan dengan postur kerja yang salah seperti posisi berdiri dan membungkuk dan dalam waktu yang lama, sehingga berpotensi risiko tinggi terhadap gangguan, nyeri, kekakuan dan ketidaknyamanan [5]. Kondisi aktivitas kerja yang memerlukan tuntutan serta tekanan fisik otot yang berat, aktivitas pengangkatan berulang, aktivitas kerja yang berulang-ulang, postur statis dan postur tubuh janggal atau tidak alamiah (awkward posture), dapat berpotensi munculnya cedera atau nyeri pinggang, kelainan dan gangguan pada sistem otot-rangka (MSDs) [4,5,13]. Tahun 2005, hasil studi dari Departemen Kesehatan menunjukkan bahwa sekitar $40,5 \%$ penyakit yang diderita pekerja sehubungan dengan pekerjaan yang dilakukannya. Menurut hasil penelitian terhadap 9.482 pekerja di 12 kabupaten/kota di Indonesia, umumnya gangguan kesehatan atau penyakit yang dialami pekerja berupa penyakit Musculoskeletal Disorders atau MSDs (16\%), kardiovaskular (8\%), gangguan saraf $(5 \%)$, gangguan pernapasan $(3 \%)$ dan gangguan Telinga, Hidung dan Tenggorokan $(1,5 \%)$ [12].

CV. XYZ adalah perusahaan yang bergerak pada proses produksi pilar di Batam, Kepulauan Riau. Waktu yang dibutuhkan untuk proses pencetakan selama 5 jam sedangkan 2 jam adalah waktu proses yang dibutuhkan operator untuk membuka cetakan dan pengamplasan pilar, sehingga total output produksi mampu menghasilkan 24 cetakan pilar pagar per harinya dengan berat tiap pilar mencapai $3 \mathrm{~kg}$. Sebagian besar aktvitas produksi pilar tersebut dilakukan secara manual, sehingga dikhawatirkan akan mempengaruhi kesehatan dan keselamatan kerja pekerja. Kajian ini difokuskan pada postur kerja operator pencetakan yaitu mengangkat dan menumpahkan semen seberat $5 \mathrm{~kg}$ dari dalam ember ke dalam cetakan, kemudian operator menaburkan pasir yang di pegang oleh salah satu tangannya seberat $2 \mathrm{~kg}$ untuk mempercepat proses pengeringan. Aktivitas tersebut dilakukan dengan postur janggal yaitu posisi tubuh operator membungkuk dengan membawa beban, jongkok dan aktivitas repetitive dalam waktu yang lama. Kondisi kerja tersebut menimbulkan keluhan rasa nyeri pada bagian leher, bahu, lengan, dan kaki setelah 8 jam operator bekerja setiap harinya, sehingga dikhawatirkan akan mempengaruhi kesehatan dan keselamatan kerja operator seperti gangguan musculoskeletal (otot, sendi serta tulang belakang). Dokumentasi postur kerja dilakukan pada saat operator melakukan aktivitas pencetakan yang dapat dilihat pada Gambar 1.

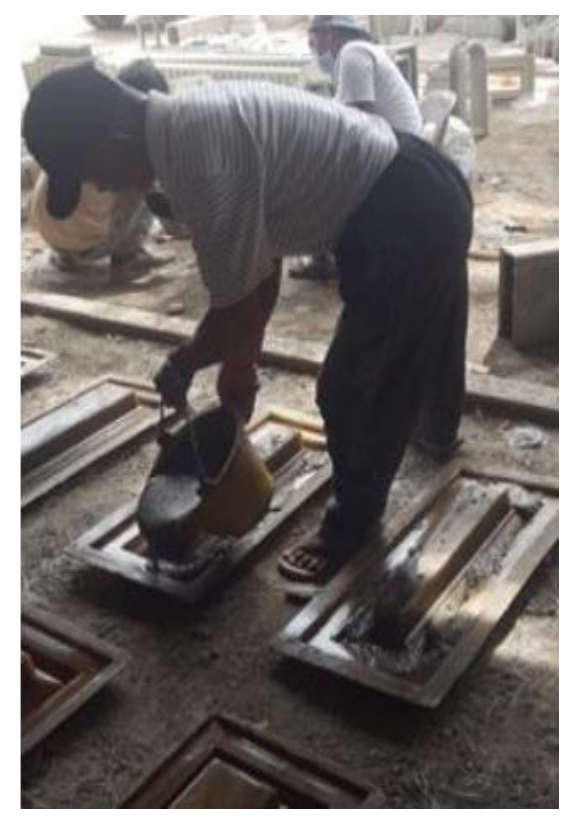

Gambar 1. Aktivitas pencetakan pilar

Gambar 1 menunjukkan bahwa pada aktivitas pencetakan pilar, operator mengalami postur kerja yang tidak alamiah (awkward posture) yaitu postur tubuh membungkuk dengan membawa beban. Postur yang benar tidak membuat tubuh condong ke depan, belakang, kiri, atau kanan [5]. Hal ini dapat diatasi dengan melakukan analisis postur kerja operator pencetakan pilar di CV. XYZ.

Analisis postur dapat menjadi teknik yang kuat untuk menilai aktivitas kerja. Penilaian risiko cedera MSDs terkait dengan postur di tempat kerja. Dari latar belakang permasalahan di atas, penulis mengambil kajian ergonomi yang berhubungan dengan postur kerja operator pencetakan pilar. Analisis postur kerja 
menggunakan metode Quick Exposure Check (QEC) dan menganalisis keluhan rasa sakit otot operator menggunakan kuesioner Nordic Body Map (NBM). Kajian ini bertujuan untuk mengidentifikasi exposure

\section{TINJAUAN PUSTAKA}

\subsection{Ergonomi}

Ergonomi merupakan suatu cabang ilmu, seni dan teknologi yang secara sistematis menggunakan informasi-infomasi tentang sifat, kemampuan, dan keterbatasan manusia dalam merancang suatu sistem kerja dan berupaya menyerasikan alat, cara dan lingkungan kerja, sehingga manusia dapat hidup dan bekerja dalam sistem tersebut dengan baik dan dapat tercapainya tujuan yang diinginkan melalui pekerjaan dengan efektif, aman, sehat dan nyaman. Tujuan utama penerapan ergonomi adalah pencapaian kualitas hidup manusia secara optimal ditempat manusia itu berada [13].

Definisi dari risiko ergonomis adalah suatu kondisi atau situasi yang dibuat secara sengaja atau tidak sengaja yang berkontribusi munculnya kondisi yang tidak sesuai dengan prinsip-prinsip ergonomi, sehingga berpotensi bahaya pada kesehatan dan kenyamanan pada saat bekerja maupun setelah bekerja [2]. Faktor risiko ergonomi merupakan faktor-faktor yang berpotensi menimbulkan kerugian atau efek negatif terhadap kesehatan sehubungan dengan ergonomi. Beberapa faktor risiko ergonomi yaitu postur tubuh, frekuensi, durasi, force atau gaya dan faktor obyek [10].

\subsection{Postur Kerja}

Berbagai kondisi dari stasiun kerja yang tidak ergonomis akan menimbulkan potur kerja yang tidak alamiah seperti jongkok, duduk membungkuk, dan sebagainya. Postur kerja merupakan posisi tubuh selama melakukan aktivitas kerja yang berhubungan dengan rancangan area kerja dan task requirement. Posisi tubuh tidak alamiah atau menyimpang secara signifikan dari posisi normal tubuh saat aktivitas kerja disebut postur janggal (awkward posture). Kebutuhan jumlah energi meningkat pada saat tubuh bekerja dalam posisi janggal. Postur janggal mudah menimbulkan lelah bagi tubuh dikarenakan kondisi perpindahan tenaga dari otot ke jaringan rangka tidak efisien. Kondisi aktivitas yang termasuk postur janggal adalah pengulangan atau waktu lama dalam posisi menggapai, berputar (twisting), memiringkan badan, berlutut, jongkok, memegang dalam kondisi statis dan menjepit dengan tangan. Postur ini melibatkan level dan rasa sakit di bagian tubuh operator yang menimbulkan risiko cedera musculoskeletal akibat postur kerja pencetakan pilar di CV. XYZ.

beberapa area tubuh seperti bahu, punggung, dan lutut, karena bagian tersebut yang paling sering mengalami cidera [7].

\subsection{Musculoskeletal}

Keluhan sistem musculoskeletal adalah keluhan pada bagian-bagian otot rangka (skeletal) yang dirasakan oleh seseorang mulai dari keluhan sangat ringan sampai sangat sakit [13]. Keluhan berupa kerusakan pada sendi, ligamen dan tendon akan terjadi jika otot menerima beban statis secara berulang dan dalam waktu yang lama, biasanya diistilahkan dengan keluhan MSDs atau cedera pada sistem musculoskeletal.

\subsection{Nordic Body Map (NBM)}

Nordic Body Map merupakan salah satu dari metode penilain subyektif untuk menilai tingkat keparahan gangguan otot skeletal individu dalam kelompok kerja. Untuk mengetahui letak rasa sakit atau ketidak nyamanan pada tubuh pekerja digunakan body map. Aplikasi NBM menggunakan lembar kerja kuesioner berupa peta tubuh (body map) yang menunjukkan bagian tubuh mana saja dari 28 bagian otot-otot skeletal yang mengalami gangguan kenyerian atau keluhan rasa sakit [13].

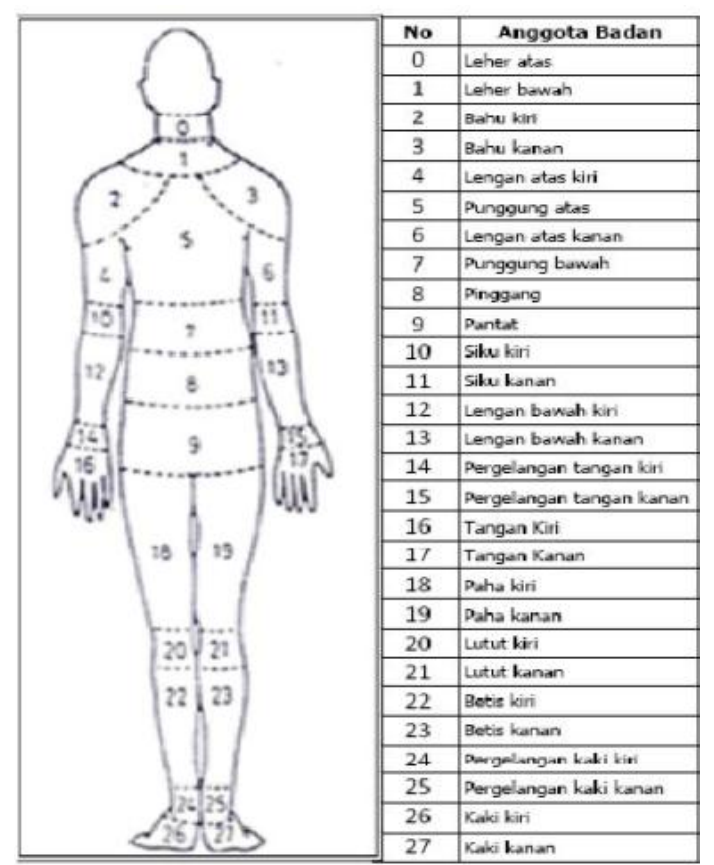

Gambar 2. Body map dalam kuesioner risiko muskuloskeletal 


\subsection{Quick Exposure Check (QEC)}

QEC merupakan salah satu metode penilaian beban postur tubuh terhadap risiko kerja yang berhubungan dengan gangguan otot di tempat kerja (work related musculoskeletal disorders - WRMSDs), diperkenalkan oleh Dr.Guanyang Li dan Peter Buckle. QEC menilai pada empat bagian area tubuh yang terpapar gangguan risiko yaitu bagian belakang punggung (back), bahu/lengan (should arm), pergelangan tangan (hand wrist), dan leher (neck) pada seseorang atau operator. Kelebihan dari metode ini karena penilaian mempertimbangkan kondisi yang dialami operator dari dua sudut pandang, yaitu worker assessment dan observer assessment [6].

Fungsi utama dari metode ini adalah sebagai berikut [1]

a. Mengidentifikasi faktor resiko terjadinya WRMSDs.

b. Mengevaluasi gangguan resiko untuk daerah/bagian tubuh yang berbeda-beda.

c. Menyarankan suatu tindakan yang perlu diambil dalam rangka mengurangi gangguan risiko yang ada.

d. Mengevaluasi efektivitas dari suatu intervensi ergonomi di tempat kerja.

e. Mendidik para pemakai tentang risiko musculoskeletal di tempat kerja.

Tujuan pengembangan QEC adalah [6]:

1. Menyelidiki atau menilai perubahan paparan pada tubuh yang berisiko terjadinya musculoskeletal sebelum dan sesudah intervensi ergonomi.

2. Mengikutsertakan pengamat dan pekerja dalam melakukan penilaian dan mengidentifikasi kemungkinan untuk perubahan pada sistem kerja.

3. Membandingkan paparan risiko cedera diantara dua orang atau lebih yang melakukan pekerjaan yang sama, atau diantara orang-orang yang melakukan pekerjaan yang berbeda.

4. Meningkatkan kesadaran dan sosialisasi diantara para manajer, engineer, desainer, praktisi keselamatan dan kesehatan kerja dan para operator mengenai faktor risiko musculoskeletal pada stasiun kerja.

Tahapan proses pengolahan data QEC adalah sebagai berikut [11]:

a. Penentuan exposure score

Penentuan exposure score dilakukan dengan menggunakan data-data kuesioner dari exposure scoring sheet untuk menentukan skor pada tiap-tiap bagian tubuh. Exposure scoring sheet akan mengkombinasikan jawaban dari kuesioner operator dan kuesioner pengamat serta memberikan skor untuk masing-masing kombinasi yang terbentuk. Perhitungan exposure score untuk masing-masing bagian tubuh seperti pada punggung, bahu atau lengan atas, pergelangan tangan, dan leher. Untuk menentukan tingkat risiko cedera pada anggota tubuh dari nilai exposure score dapat dilihat pada Tabel 1 [3].

Tabel 1. Exposure score QEC

\begin{tabular}{|l|c|c|c|c|}
\hline \multirow{2}{*}{\multicolumn{1}{|c|}{ Score }} & \multicolumn{4}{c|}{ Exposure Score } \\
\cline { 2 - 5 } & Low & Moderate & High & Very High \\
\hline Punggung (statis) & $8-15$ & $16-22$ & $23-29$ & $29-14$ \\
\hline Punggung (bergerak) & $10-20$ & $21-30$ & $31-40$ & $41-56$ \\
\hline Bahu/Lengan & $10-20$ & $21-30$ & $31-40$ & $41-56$ \\
\hline Pergelangan Tangan & $10-20$ & $21-30$ & $31-40$ & $41-56$ \\
\hline Leher & $4-6$ & $8-10$ & $12-14$ & $16-18$ \\
\hline
\end{tabular}

b. Penentuan exposure level (E)

Nilai exposure level berdasarkan hasil penghitungan nilai exposure score yaitu hasil persentase antara total skor aktual exposure (X) dengan total skor maksimum (Xmaks), perhitungan nilai exposure level dengan rumus:

$$
\mathrm{E}(\%)=\frac{X}{X_{\text {maks }}} \times 100 \%
$$

Dimana:

$\mathrm{X}=$ Total skor diperoleh dari perhitungan kuesioner terhadap postur atau risiko cedera pada punggung, leher, bahu/lengan, dan pergelangan tangan.

Xmaks $=$ Total skor maksimum terhadap potur kerja yang mungkin terjadi pada punggung, bahu/lengan, pergelangan tangan, dan leher.

Ketentuan pemberian skor maksimum (Xmaks = 162), jika tipe aktivitas adalah statis, termasuk duduk atau berdiri dengan/tanpa pengulangan (repetitive) yang sering dan penggunaan tenaga/beban yang relative rendah. Sedangkan pemberian skor maksimum $(X m a k s=176)$, jika dilakukan aktivitas manual handling, yaitu mengangkat, mondorong, menarik, dan membawa beban. Untuk menentukan tindakan yang akan dilakukan setelah perhitungan nilai exposure level dapat dilihat pada Tabel 2 [3].

Tabel 2. Action level QEC 


\begin{tabular}{|c|c|}
\hline Total Exposure Level & Action \\
\hline$<40 \%$ & Aman \\
\hline $40-49 \%$ & Perlu penelitian lebih lanjut \\
\hline $50-69 \%$ & Perlu penelitian lebih lanjut dan dilakukan perubahan \\
\hline$\geq 70 \%$ & Dilakukan penelitian dan perubahan secepatnya \\
\hline
\end{tabular}

c. Penentuan Kategori Resiko

\section{METODE PENELITIAN}

Jenis penelitian ini adalah deskriptif dan survei. Metode deskriptif adalah metode yang digunakan untuk meneliti status dan memaparkan pemecahan masalah terhadap suatu masalah aktual berdasarkan data dari sekelompok manusia, suatu obyek, suatu kondisi, suatu peristiwa saat ini [8]. Survei adalah metode penelitian dengan menggunakan kuesioner sebagai instrument pengumpulan datanya [9]. Penelitian ini bertujuan untuk menyelidiki dampak dari pekerjaan yang dilakukan oleh postur kerja operator pencetakan pilar. Pengukuran dan analisis tingkat risiko musculoskeletal dilakukan dengan menggunakan metode Quick Exposure Check (QEC) dan untuk menilai klasifikasi subjektivitas tingkat keparahan (severity) yang dirasakan tubuh operator atas terjadinya gangguan musculoskeletal melalui metode kuesioner NBM (Nordic Body Map). Responden yang digunakan dalam penelitian ini yaitu enam operator CV. XYZ pada saat bekerja di aktivitas produksi pencetakan pilar.

\section{HASIL DAN PEMBAHASAN}

Aktivitas pencetakan pilar dilakukan oleh operator secara manual dan repetitif dalam waktu yang lama dengan postur kerja yang janggal. Untuk mengukur dan analisis tingkat keluhan musculoskeletal, maka dilakukan penyebaran kuesioner QEC pada responden. Berdasarkan pengamatan di lapangan, metode QEC sesuai digunakan pada penilaian aktivitas pencetakan di CV. XYZ karena fokus kajian pada tubuh bagian atas dalam menyelesaikan pekerjaannya.

Kuesioner QEC diberikan dan diisi oleh seluruh operator yang bekerja pada proses pencetakan dan pengamat yang melihat bagaimana postur tubuh operator ketika bekerja. Penilaian keluhan musculoskeletal melalui QEC berdasarkan isi jawaban dilakukan oleh pengamat/peneliti dan operator/pekerja. Pengisian kuesioner pengamat untuk mengetahui postur tubuh yang terbentuk oleh operator ketika melakukan pekerjaannya. Sedangkan pengisian kuesioner operator
Dari hasil perhitungan exposure level maka dapat dilakukan pengkategorian risiko dan level tindakan yang diperlukan untuk aktivitas tersebut berdasarkan nilai hasil perhitungan total exposure score.

untuk mengetahui kondisi yang dirasakan operator ketika melakukan pekerjaannya. Data yang dikumpulkan yaitu data postur kerja operator yang berjumlah enam orang.

Rekapitulasi hasil jawaban kuesioner pengamat dan operator dari aktivitas pencetakan pilar yang diteliti kemudian dilakukan perhitungan pada lembar skor QEC untuk memperoleh hasil perhitungan exposure score yang dapat dilihat pada Tabel 3 .

Tabel 3. Rekapitulasi exposure score operator

\begin{tabular}{|l|c|c|c|c|c|c|}
\hline \multirow{2}{*}{$\begin{array}{c}\text { Anggota tubuh } \\
\text { yang diamati }\end{array}$} & \multicolumn{5}{|c|}{$\begin{array}{c}\text { Nilai exposure score } \\
\text { operator pencetakan }\end{array}$} \\
\cline { 2 - 7 } & 1 & 2 & 3 & 4 & 5 & 6 \\
\hline Punggung & 36 & 32 & 36 & 42 & 32 & 40 \\
\hline Bahu/lengan & 36 & 36 & 36 & 42 & 30 & 34 \\
\hline Pergelangan tangan & 38 & 38 & 36 & 42 & 32 & 38 \\
\hline Leher & 24 & 27 & 19 & 39 & 18 & 27 \\
\hline Total exposure score & 135 & 135 & 130 & 169 & 117 & 145 \\
\hline
\end{tabular}

Dari Tabel 3 hasil dari perhitungan exposure score diperoleh tingkat risiko yang menimbulkan keluhan atau cedera pada punggung, bahu/lengan dan pergelangan operator 4 dalam kategori Very High dibandingkan dengan operator lainnya, hal ini bermakna bahwa operator 4 ketika melakukan aktivitas pencetakan pilar lebih terkena paparan risiko cidera pada beberapa anggota tubuh dibandingkan operator lainnya. Sedangkan tingkat risiko cedera pada punggung, bahu atau lengan dan pergelangan tangan operator 1, 2, 3, 5, dan 6 dalam kategori High ketika melakukan aktivitas pencetakan pilar. Untuk tingkat risiko cedera musculoskeletal pada leher seluruh operator dalam kategori Moderate.

Hasil dari perhitungan exposure score ini kemudian digunakan untuk menghitung nilai exposure level dan tindakan lebih lanjut yang diberikan pada operator. Rekapitulasi dari hasil perhitungan exposure level dapat dilihat pada Tabel 4 [3]. 
Tabel 4. Rekapitulasi exposure level operator

\begin{tabular}{|c|c|c|}
\hline Operator & Exposure level & Tindakan \\
\hline 1 & $76,70 \%$ & Dilakukan penelitian dan perubahan secepatnya \\
\hline 2 & $76,70 \%$ & Dilakukan penelitian dan perubahan secepatnya \\
\hline 3 & $73,86 \%$ & Dilakukan penelitian dan perubahan secepatnya \\
\hline 4 & $96,02 \%$ & Dilakukan penelitian dan perubahan secepatnya \\
\hline 5 & $66,48 \%$ & Perlu penelitian lebih lanjut dan dilakukan perubahan \\
\hline 6 & $82,39 \%$ & Dilakukan penelitian dan perubahan secepatnya \\
\hline
\end{tabular}

Rekapitulasi hasil perhitungan exposure level pada enam operator pencetakan pilar yang ditunjukkan pada Tabel 4, diperoleh rentang nilai antara 73,86\%-96,02\% dan nilai rata-rata exposure level sebesar $78,69 \%$. Hasil perhitungan pada operator 5 menunjukkan exposure level sebesar $66,48 \%$, hal ini berarti untuk operator ini perlu penelitian lebih lanjut dan dilakukan perubahan terhadap postur kerjanya. Sedangkan hasil nilai pada kelima operator pencetakan pilar lainnya di CV ini menunjukkan exposure level $\geq 70 \%$ yang menyebabkan tingginya tingkat keluhan musculoskeletal, sehingga perlu dilakukan penelitian dan perubahan secepatnya terhadap postur kerja untuk menghindari adanya risiko cedera musculoskeletal yang semakin parah.

Kuesioner NBM diberikan kepada seluruh operator pencetakan pilar. Kuesioner ini diisi oleh sampel untuk menunjukkan ada atau tidaknya gangguan nyeri atau sakit yang dirasakan pada bagian-bagian tubuh operator. Hasil akhir dari kuesioner NBM dapat dilihat pada Gambar 3 berikut:

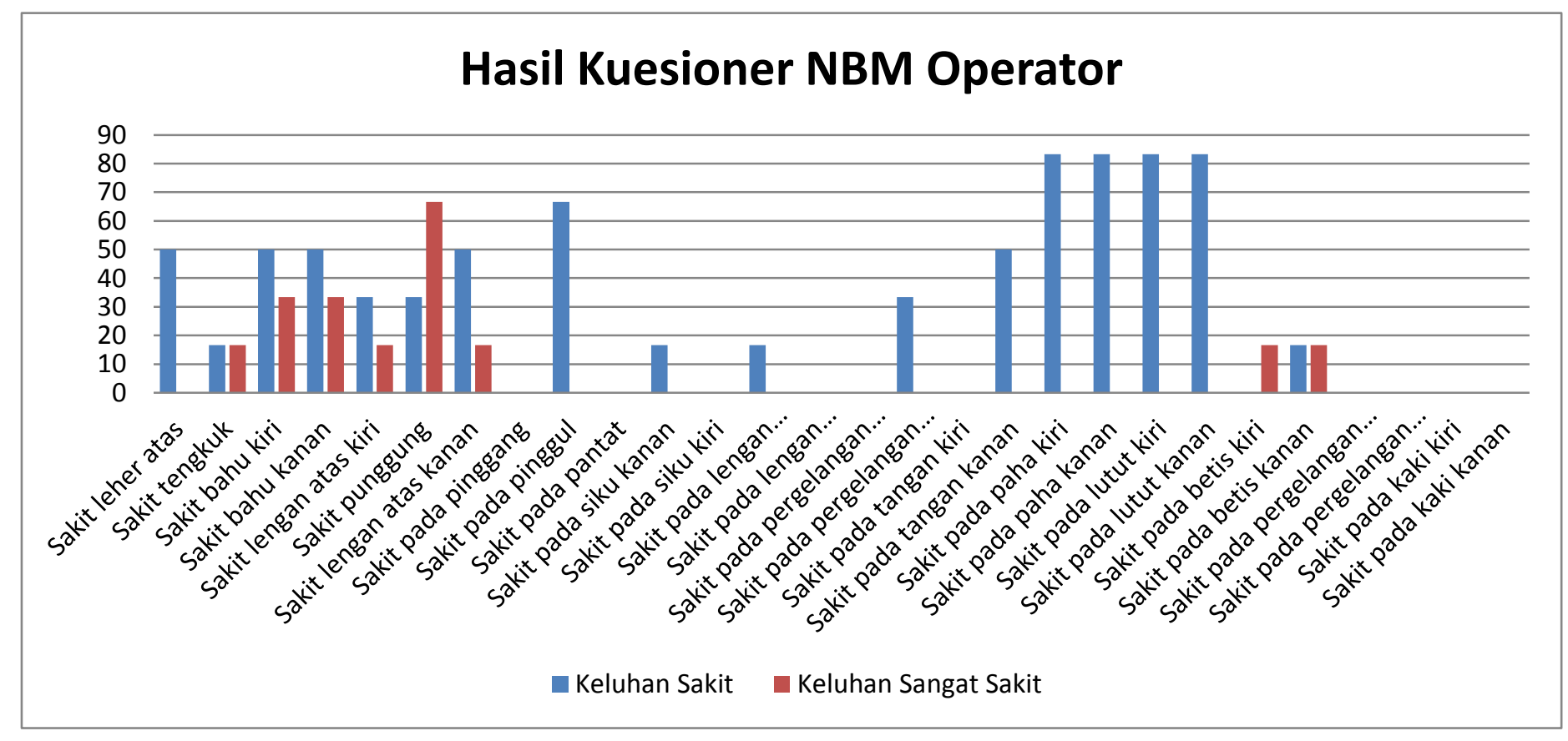

Gambar 3. Diagram hasil kuesioner NBM 
Hasil kuesioner NBM dapat diartikan bahwa pekerjaan aktivitas pencetakan pilar yang dilakukan operator termasuk pekerjaan yang memiliki tingkat risiko sangat tinggi, karena seluruh operator mengalami sebanyak 124 keluhan tingkat keparahan rasa agak sakit, sakit dan sangat sakit pada bagian tubuh tertentu. Hasil NBM seluruh operator secara subjektivitas menunjukkan tingkat keparahan (severity) yang berisiko musculoskeletal tinggi, karena itu diperlukan tindakan perbaikan segera.

Dari Gambar 3, dapat dilihat bahwa bagian tubuh operator yang paling dominan tingkat keparahan rasa sakit atas gangguan musculoskeletal adalah leher sebesar $50 \%$, bahu kiri dan bahu kanan masing-masing sebesar $50 \%$, pinggul sebesar $66,67 \%$, paha kiri dan paha kanan masing-masing sebesar $83,33 \%$, lutut kiri dan lutut kanan masing-masing sebesar $83,33 \%$ dan lengan atas kanan sebesar $66,67 \%$. Sedangkan bagian tubuh operator yang paling dominan tingkat keparahan rasa sangat sakit atas gangguan musculoskeletal adalah punggung sebesar $66,67 \%$. Hal ini terjadi dikarenakan operator bekerja dengan posisi membungkuk setiap harinya dan bagian bawah tubuh (lutut dan kaki) sebagai penahan tubuh operator ketika bekerja.

Risiko tinggi ini dapat mempengaruhi kesehatan dan keselamatan kerja dan mengakibatkan penyakit akibat kerja seperti musculoskeletal disorders. Jika hal ini diabaikan akan menimbulkan rasa sakit dalam jangka waktu tertentu yang menyebabkan terjadinya WRMD (Work-Related Musculoskeletal Disorders), yaitu sekumpulan gangguan sistem musculoskeletal menyangkut otot, tendon dan syaraf yang diakibatkan oleh postur janggal operator pencetakan pilar yang dilakukan secara repetitive. Apabila aktivitas operator pencetakan pilar tidak melakukan tindakan alternatif solusi postur kerja yang benar, maka keluhan musculoskeletal disorders yang dialami oleh para operator akan semakin parah. Hal tersebut akan mengakibatkan kerugian bagi opertor dan CV. XYZ.

Alternatif tindakan bagi operator di CV. XYZ untuk mengurangi rasa sakit atas risiko musculoskeletal di beberapa bagian tubuh seperti leher, pinggul, paha, lutut, punggung, dan lengan atas adalah memperbaiki postur tubuh operator pada aktivitas pencetakan pilar dengan memberikan arahan kepada operator cara kerja yang benar dan baik serta merancang meja kerja pencetakan pilar yang ergonomis. Perbaikan ini diberikan untuk mengurangi dampak dari efek pekerjaan yang timbul.
Hal ini dirasa mampu memberikan tingkat ergonomis yang lebih baik bagi postur kerja operator pencetakan pilar di CV. XYZ, agar tidak mengakibatkan risiko cedera musculoskeletal yang berakibat pada kerugian di CV. XYZ.

\section{KESIMPULAN}

Adapun kesimpulan dari kajian ini adalah postur kerja dari operator yang dinilai menggunakan QEC pada aktivitas pencetakan pilar. Pada aktivitas tersebut diperoleh nilai exposure score untuk masing-masing operator sebesar 135, 135, 130, 169, 117, dan 145 . Sedangkan hasil nilai exposure level pada aktivitas pencetakan pilar sebesar 76,70\%, 76,70\%, 73,86\%, $96,02 \%, 66,48 \%$ dan $82,39 \%$. Hasil perhitungan pada operator 5 menunjukkan exposure level sebesar 66,48\%, hal ini berarti untuk operator ini perlu penelitian lebih lanjut dan dilakukan perubahan terhadap postur kerjanya. Untuk hasil nilai pada kelima operator pencetakan pilar lainnya menunjukkan exposure level $\geq$ $70 \%$ yang menyebabkan tingginya tingkat risiko musculoskeletal. Sedangkan berdasarkan kusioner NBM, dapat dilihat bahwa bagian tubuh operator yang paling dominan tingkat keparahan rasa sakit atas gangguan musculoskeletal adalah leher sebesar 50\%, bahu kiri dan bahu kanan masing-masing sebesar 50\%, pinggul sebesar 66,67\%, paha kiri dan paha kanan masingmasing sebesar 83,33\%, lutut kiri dan lutut kanan masing-masing sebesar 83,33\% dan lengan atas kanan sebesar $66,67 \%$. Sedangkan bagian tubuh operator yang paling dominan tingkat keparahan rasa sangat sakit atas gangguan musculoskeletal adalah punggung sebesar $66,67 \%$. Tindakan atau perbaikan yang diberikan kepada operator adalah memberikan arahan kepada operator cara kerja yang benar dan baik serta merancang meja kerja pencetakan pilar yang ergonomis. Hal ini dirasa mampu memberikan tingkat ergonomis yang lebih baik bagi postur kerja operator pencetakan pilar di CV. XYZ.

\section{DAFTAR PUSTAKA}

[1] Andriani, M; Dewiyana; Elis Erfani., "Perancangan Ulang Egrek Yang Ergonomis Untuk Meningkatkan Produktivitas Pekerja Pada Saat Memanen Sawit", JISI, vol. 4, no. 2, hal:119-128, Agustus, 2017.

[2] Azmi, N; Maharani, R.H; Faradilla, A., "Intervensi Ergonomi Untuk Mengurangi Risiko 
Musculosceletal Disorder Operator Mesin Injeksi Oembuatan Kursi Plastik", dalam Prosiding: Seminar Nasional dan Kongres Perhimpunan Ergonomi Indonesia (PEI) Ke-VIII, Medan, 2018, hal. IE.36 -IE.43.

[3] Ilman, A; Yuniar; Helianty, Y., "Rancangan Perbaikan Sistem Kerja dengan Metode Quick Exposure Check (QEC) di Bengkel Sepatu X di Cibaduyut". Reka Integra, vol. 1, no. 2, hal: 120128, Oktober, 2013.

[4] Iridiastadi, H; Yassierli., "Biomekanika Kerja" dalam Ergonomi: Suatu Pengantar. Bandung: PT. Remaja Rosdakarya. 2014, hal 60-75.

[5] I Rizkya; K Syahputri; R M Sari; Anizar; I Siregar., "Evaluation of work posture and quantification of fatigue by Rapid Entire Body Assessment (REBA).", dalam IOP Conf. Ser.: Mater. Sci. Eng. 309 012051, 2018.

[6] Li, G. dan Buckle, P. "A Practical Method For The Assesment Of Work-Related Musculoskeletal Risks - Quick Exposure Check (QEC)", dalam In: Proceedings of The Human Factors and Ergonomics Society 42nd Annual Meeting, Chicago, October, 1998.

[7] Maharani, B.P., Budi, A; Nurhasanah, N., "Usulan Perbaikan Postur Kerja Karyawawn CV Atham Toy's Mainan Kayu (ATMIK) Dengan Metode
Quick Exposure Check”, Jurnal Pasti, vol. IX, no 3, hal: 238-247, 2014.

[8] Nazir, "Metode Penelitian", Jakarta: Salemba Empat, 2003.

[9] Panjaitan, N; Hario, M., "Analisis Postur Pekerja Di Stasiun Bagging" dalam Prosiding: Seminar Nasional dan Kongres Perhimpunan Ergonomi Indonesia (PEI) Ke-VIII , Medan, 2018, hal: IE.67IE.71.

[10]Purbasari, A; Siboro, B.A.H., “Analisis Sikap Kerja Terhadap Faktor Risiko Ergonomi Pada Kerja Assembly Manual (Studi Kasus: Laboratorium Teknik Industri Universitas Riau Kepulauan)", dalam Profisiensi, vol.6, no.1, hal: 8-15, Juni, 2018.

[11]Sari, F.P; Suhardi, B; Astuti, R.D., "Penilaian Postur Kerja di Area Konstruksi CV. Valasindo dengan Metode Quick Exposure Check", Peforma, vol. 16, no.2, hal: 107-113, 2017.

[12]Sumiati., "Analisis Risiko Low Back Pain (LBP) Pada Perawat Unit Darurat Dan Ruang Rawat Operasi Di RS. Prikasih, Jakarta Selatan", Skripsi Fakultas Kesehatan Masyarakat, Universitas Indonesia, Depok, 2007.

[13]Tarwaka, "Penilaian Resiko Gangguang Sistem Muskuloskeletal" dalam Ergonomi Industri: DasarDasar Pengetahuan Ergonomi Dan Aplikasi Di Tempat Kerja. Solo: Harapan Press, 2010, hal: 338342. 